\title{
Research on Higher Vocational College English Teaching Mode Reform and Innovation
}

\author{
Feng Li \\ Chongqing Three Gorges Vocational College, Wanzhou, Chongqing 404155, China
}

Key words: Vocational colleges; Teaching reform; Innovation research

Abstract: In recent years, China has in-depth economic development in language market, and foreign exchange has also been strengthened. The application of English has been rapidly penetrated into all aspects, and the society needs talents who master English and can use English freely. However, traditional English teaching mode of higher vocational colleges is unable to meet this demand and vocational college English teaching model reform is imperative. This paper analyzes the current English teaching mode in higher vocational colleges, lists the problems and causes of current teaching, and on the basis of which finds a reform way for these problems and provides help for higher vocational colleges' reform in teaching ideas, classroom mode, teaching content, inspection methods and other aspects.

\section{INTRODUCTION}

In recent years, higher vocational colleges have experienced a long and tortuous development in English teaching and have made remarkable progress. We can see that vocational colleges have cultivated high-volume proficient English talents and versatile talents who can carry out various aspects communication. These talented people play an important and obvious role in today's society, but we can still very clearly find that there are a variety of problems in students' practical application process. Students' innovation is even extremely weak and their comprehensive quality has not reached "Higher Vocational College English Outline" requirements [1].

At present, China has successfully become a member of WTO organization, and foreign affairs and international exchanges have become increasingly frequent. Therefore, the demand for professional and technical talents and compound talents who are proficient in English of all types of enterprises and units is growing.

The teaching reform in China has been continuously strengthened and is in in-depth state, but it is precisely because of our country's increasing and strengthening support of higher vocational education efforts that puts forward higher requirements for higher vocational and technical education. English has always been one of the skills higher vocational college students must master. But as in the previous analysis, there are still many drawbacks in current English teaching in China's vocational colleges.

"The ultimate goal of education is not to teach what we already have, but to guide us to the creativity of mankind and awaken the vitality and sense of value of the students," said Sprint, the founder of modern pedagogy. We can see that we are not only asking teachers to have a very high academic level, a wide range of knowledge and the ability to harness new knowledge, but also the sense of innovation in order to cultivate talented, 
highly skilled and innovative talents and to provide students ways and means access to new knowledge. Only with the sense of innovation can teachers enable students to fully develop their ability in language usage [2]. Therefore, according to the characteristics of students in vocational colleges, the most important thing for teachers in actual English teaching process is to highlight the learning subjects---- students' participation in the teaching, highlighting the practicality of teaching content, teachers' guidance in teaching process and the practical operability of teaching methods. These aspects of strengthening can enhance students' comprehensive ability of English practical application.

\section{Present Situation of English Teaching in Higher Vocational Colleges}

Vocational students' English level. Higher vocational college students are generally admitted with lower scores. They received high school education and have learned English, but because of poor learning habits, their English level is low with small amount of words and they are bad in reading, writing, reading and speaking. A considerable part of the students has a sense of conflict in learning English and they have no good learning enthusiasm, no interest in English learning, and because of low learning level and bad learning way they find it more difficult in the process of learning English. They do not know how to improve their English level, and various reasons make vocational students lose confidence in the process of learning English [3].

Higher vocational college faculty. Apart from students' low learning level which affects teaching effect, faculty strength is also an extremely important factor. At present, English teaching faculty in higher vocational colleges are mostly graduated from English major, but because of the lack of professional training and technical guidance, they cannot use efficient method to teach students. The shortage of teachers is also a common problem in various vocational colleges, which increases the teaching burden of teachers in vocational colleges. Strong workload makes college teachers lack extra time to prepare lessons and no energy to study new teaching ideas, better teaching models and teaching methods. In addition, the salary of college teachers is low, and most of the college teachers have to seek other part-time work to guarantee the quality of life, which also greatly affects the quality of teaching in colleges and universities.

Classroom teaching model. English teaching is not just important in higher vocational college teaching. It is a necessary teaching task, which requires teachers in vocational colleges to effectively develop students' application skills and practical skills. Students are to master the knowledge in syllabus requirements and can use it proficiently in life. But many vocational English teachers cannot meet the goal requirements. In addition, many vocational college students are very weak in listening, speaking, reading and writing and vocational school teachers still use narrative teaching and one-way indoctrination in teaching, making that classroom atmosphere is not vivid and students do not have enthusiasm.

The selection of teaching materials. Teaching material is the core of teaching process, which is an important means to help teachers achieve teaching objectives. If you cannot ensure the quality of teaching materials, teaching effectiveness will be directly affected. However, current vocational colleges are disorganized in the selection of teaching 
materials and lack target for current vocational students' competence level. Most of the colleges use ordinary college teaching materials or use school teachers' own teaching materials. However, the contents of ordinary colleges and universities teaching materials are all based on the solid foundation of English undergraduates, so for vocational college students, the content is too difficult with too much knowledge and deep theories. Vocational students cannot well absorb it and lose interest. School teachers' own teaching material is lack of professional research and practice, and most of the materials is from undergraduate textbooks without good conversion, making the textbooks both break the original textbook integrity and lack professional learning materials, and cannot systematically set up teaching ideas for students in vocational colleges. There are some vocational colleges using situational teaching and some even directly apply foreign teaching methods in order to improve the quality of teaching by using more innovative ways, but because of lack of practice, they obtain counterproductive effect without considering their own culture.

\section{The Reform of English Teaching Mode in Higher Vocational Colleges}

In summary, the teaching methods in higher vocational colleges have too many defects, and the current model reform has been imperative.

Teaching reform. Now there is a wide range of textbooks in the market, which are of uneven strengths in profession and focus. Vocational colleges should choose their own level of teaching materials. The choice of English teaching materials in higher vocational colleges should meet the following requirements:

Targeted. Teaching students in accordance of their aptitude embodies in teaching materials. Teaching materials that are best suited to the level of teaching students can make students learn the most useful knowledge in the shortest possible time and can really learn to use it.

Moderate difficulty. Higher vocational college English teaching is different from high school English teaching. The teaching requirements have been raised, which requires vocational colleges' English textbooks not too simple and have a certain degree of high altitudes. However, students in vocational colleges are weak in learning level and their learning habits and learning ability are weaker than those of ordinary undergraduates. Therefore, if we choose high-level teaching materials, students will feel them difficult to understand and accept and lose their interest in learning. It can be seen that the choice of moderate difficulty textbooks is necessary.

Interesting. One-way inculcation of the teaching material is too rigid, and students will lose interest and have no learning will. Lively teaching materials can promote students interested in learning and exercise students' divergent thinking.

Independent listening and speaking materials. In addition to reading and writing abilities, listening and speaking abilities in practical application are also essential. It is necessary for the school to select independent listening and speaking materials to exercise students' abilities in this respect, rather than allowing students to respond only to examinations after receiving higher education and cannot really apply them to daily communication [4].

Excellent educational environment. Good educational environment can ensure the 
quality of teaching. The state should take legislative way to protect capital investment in the development process of higher vocational and technical education, in order to avoid the difficulties and problems brought about by the shortage of funds. In addition, higher vocational and technical college can cooperate with enterprises and encourage enterprises to bring in business to college. Cooperative school can provide students with good employment opportunities, create scientific teaching venues, and set up courses in line with market needs.

English faculty selection. Faculty resources are always the core resources of education process. High level and high quality faculty with professional ability and rich cultural background can guarantee the school's teaching quality. Higher vocational colleges should take a strategic vision to look at the selection of teachers and strengthen in terms of investment needs. For excellent young teachers, the school can use training to let them grow up quickly and we can send young teachers to the cooperative schools at home and abroad to learn and introduce their advanced teaching philosophy and teaching methods. Second, the school also needs to introduce professors with rich teaching experience so as to teach their years of teaching experience.

In terms of teaching tasks, schools should make each teacher have their own strengths. According to the advantages of teachers, arrange their own courses so as to both ensure the quality of teaching and reduce teacher's lesson preparation and teaching burden. Students can also feel different teachers' style of teaching.

Of course, the school should also provide teachers with independent learning channels so that teachers can not only provide training through the school for further study, but also enrich their professional knowledge and improve their professionalism through network classroom and library resources.

At the same time the school also needs large quantities of foreign teachers. Foreign teachers' authentic pure pronunciation allows students to have better listening and speaking abilities. Chinese and foreign teachers can discuss the curriculum to enrich classroom content and activate classroom atmosphere so that the teaching effect can be improved.

Build hierarchical teaching model. In vocational English teaching reform, hierarchical teaching must be the final path choice. This teaching model conforms to construction theory and pluralism theory. Hierarchical teaching model emphasizes the differences of students and teaching is for different levels of students, so this teaching model can solve the problem of individual students' lack of ability and cannot complete the overall goal. "Progressive" mechanism can also promote the enthusiasm of students to learn English, enhance students' upward mobility to learn English and stimulate their enthusiasm of learning English. Students are more confident and more like learning English. Learn will have more improvements with less effort. This kind of learning state allows the overall quality of English teaching to be improved.

Teachers have to stratify students according to different learning ability, and do a good job in statistics. In classroom, give targeted teaching. Teachers should make different learning plans for different levels of students with different learning objectives to match the student's learning plan and learning objectives so as to enable students to study with high proficiency. And the appropriate results can stimulate students more confident and 
motivated to learn.

Encouragement mechanisms and evaluation systems are also vital means for schools to conduct regular tests. Set up class awards or individual scholarships to motivate students to learn. This method is particularly able to cultivate self-confidence and sense of competition in students with weak learning ability.

Through teacher's evaluation and encouragement, students will continue to find themselves in learning process with self-understanding and self-improvement, experience progress and success, and all-round develop their English ability [5].

\section{Conclusion}

Through the study, we can clearly understand that current vocational colleges' English teaching still has many problems. If we do not reform and strengthen faculty team, the goal to cultivate complex and high quality talents will be difficult to achieve.

For higher vocational colleges, developing students' application ability will be the ultimate goal. Schools need to establish a good learning environment and use effective methods to stimulate students' enthusiasm for learning so that students can apply the theory knowledge they learned to practice. The high-end technical talents who can free use English in communication in line with social needs can be cultivated.

\section{References}

[1] Chen Shaofeng. Reflections on higher vocational colleges English teaching reform and the cultivation of innovative talents [J]. Journal of Hebei Radio \& TV University, 2010, 15(5):57-59.

[2] Yang Hua. On the reform and innovation of English teaching mode in higher vocational colleges [J]. Journal of Taiyuan Urban Vocational College, 2008 (3): 57-58.

[3] Liang Min. A new study on the reform of English classroom teaching in vocational colleges [J]. Journal of Henan Electromechanical College, 2009, 17 (6): 143-145.

[4] Tu Xifang. Vocational college English listening and speaking teaching reform model [J]. Vocational Education Research, 2011 (3): 23-24.

[5] Ni Fang. Research on the innovation of English teaching mode in higher vocational education [J]. Journal of Suzhou Education College, 2011, 14 (4): 58-60. 